\section{Microgomphus souteri Fraser, a new addition to the Odonata (Insecta) fauna of Kerala, southern India}

\section{K.G. Emiliyamma ${ }^{1}$, Muhamed Jafer Palot ${ }^{2}$ \& C. Radhakrishnan ${ }^{3}$}

1,2,3 Zoological Survey of India, Western Ghat Regional Centre, Jaferkhan Colony, Eranhipalam P.O., Kozhikode, Kerala 673006, India

Email: ${ }^{1}$ kgemily@gmail.com (corresponding author),

2 palot.zsi@gmail.com, ${ }^{3}$ radhakrishnan.zsi@gmail.com

The Odonata fauna of Kerala comprises 138 species, representing 80 genera and 12 families (Emiliyamma \& Radhakrishnan 2006; Emiliyamma et al. 2007). The present report adds an additional record from Kerala.

During a faunistic survey tour conducted on 6 June 2010 in the Aralam Wildlife Sanctuary (between $11^{0} 53^{\prime} 1^{\prime \prime}-11^{0} 59^{\prime} 14^{\prime \prime} \mathrm{N}$ and $\left.75^{\circ} 47^{\prime} 29^{\prime \prime}-75^{\circ} 55^{\prime} 58^{\prime \prime} \mathrm{E}\right)$, located in the Brahmagiri slopes of the northern Western Ghats in the Kannur District of Kerala, we collected a specimen of Microgomphus souteri Fraser, 1924 at Valayamchal. The specimen was collected at around $0200 \mathrm{hr}$ below a tube light. The weather was rainy and windy all through the day and night and the surroundings were thoroughly drenched. It is conjectured that the weather conditions might have prompted the species to come to the light at night.

Date of publication (online): 26 June 2012

Date of publication (print): 26 June 2012

ISSN 0974-7907 (online) | 0974-7893 (print)

Editor: Albert Orr

Manuscript details:

Ms \# 02885

Received 27 July 2011

Final received 11 May 2012

Finally accepted 01 June 2012

Citation: Emiliyamma, K.G., M.J. Palot \& C. Radhakrishnan (2012) Microgomphus souteri Fraser, a new addition to the Odonata (Insecta) fauna of Kerala, southern India. Journal of Threatened Taxa 4(6): 2667-2669.

Copyright: () K.G. Emiliyamma, Muhamed Jafer Palot \& C. Radhakrishnan 2012. Creative Commons Attribution 3.0 Unported License. JoTT allows unrestricted use of this article in any medium for non-profit purposes, reproduction and distribution by providing adequate credit to the authors and the source of publication.

Acknowledgements: The authors are grateful to the Director, Zoological Survey of India, Kolkata for facilities and encouragement. Thanks are also due to Shri. K.V. Uthaman, Wildlife Warden, Aralam WLS for the permission accorded to conduct the field trip in the conservation area.

OPEN ACCESS | FREE DOWNLOAD
The genus Microgomphus belongs to the family Gomphidae. Its members are among the smallest species in the family, and are coloured black marked with greenish-yellow. The genus Microgomphus is defined by the following characters: Discoidal cell of forewing and hindwing different in shape, that of forewing shorter than in hindwing; incomplete basal antenodal nervure absent; superior anal appendages with an inner branch, inferior appendages slightly notched at the tips (Image 1), further they have more than two transverse nervures between the sectors of the arc, from arc to bifurcation of Rs (Radial Sector) in fore and in hindwing.

They are distributed in the humid parts of the Western Ghats and the northeastern part of India at an elevation of $609.5 \mathrm{~m}$ and above. Other species of the genus are distributed in Myanmar, Malaysia, Sumatra, Singapore, Sri Lanka, Cambodia, Laos, Vietnam, Borneo and Africa. Species of the genus are arboreal by nature, but occasionally the males descend and settle on rocks in midstream; they do not wander far from their parent streams, and may be found settled on vegetation, usually beside the water. The larvae breed in deep pools in lowland and submontane streams flowing through heavy primary rainforest (Fraser 1934). The genus Microgomphus is represented in India by four species: $M$. chelifer Selys, 1858, M.

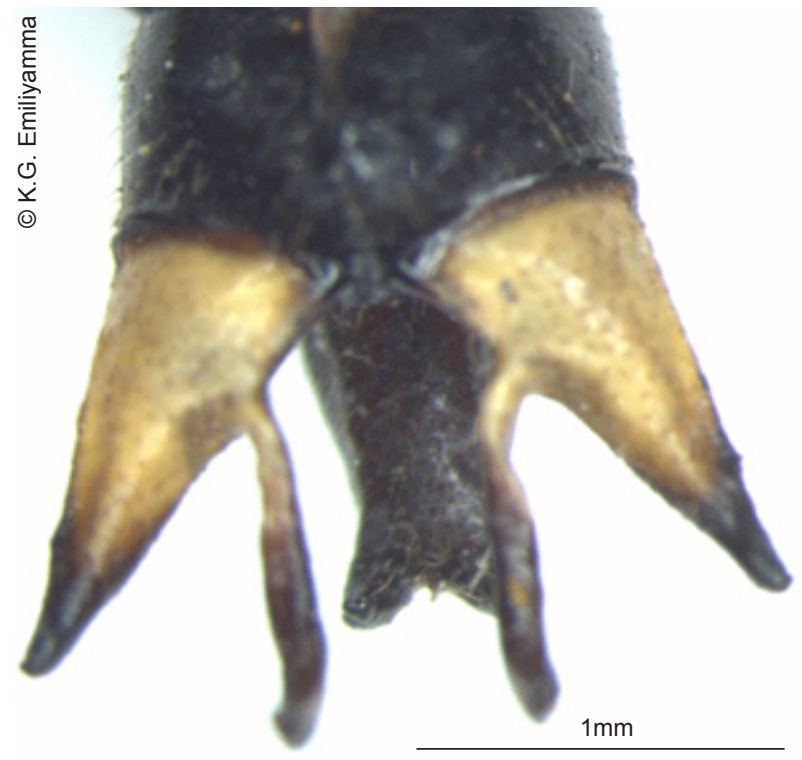

Image 1. Male anal appendages of Microgomphus souteri 


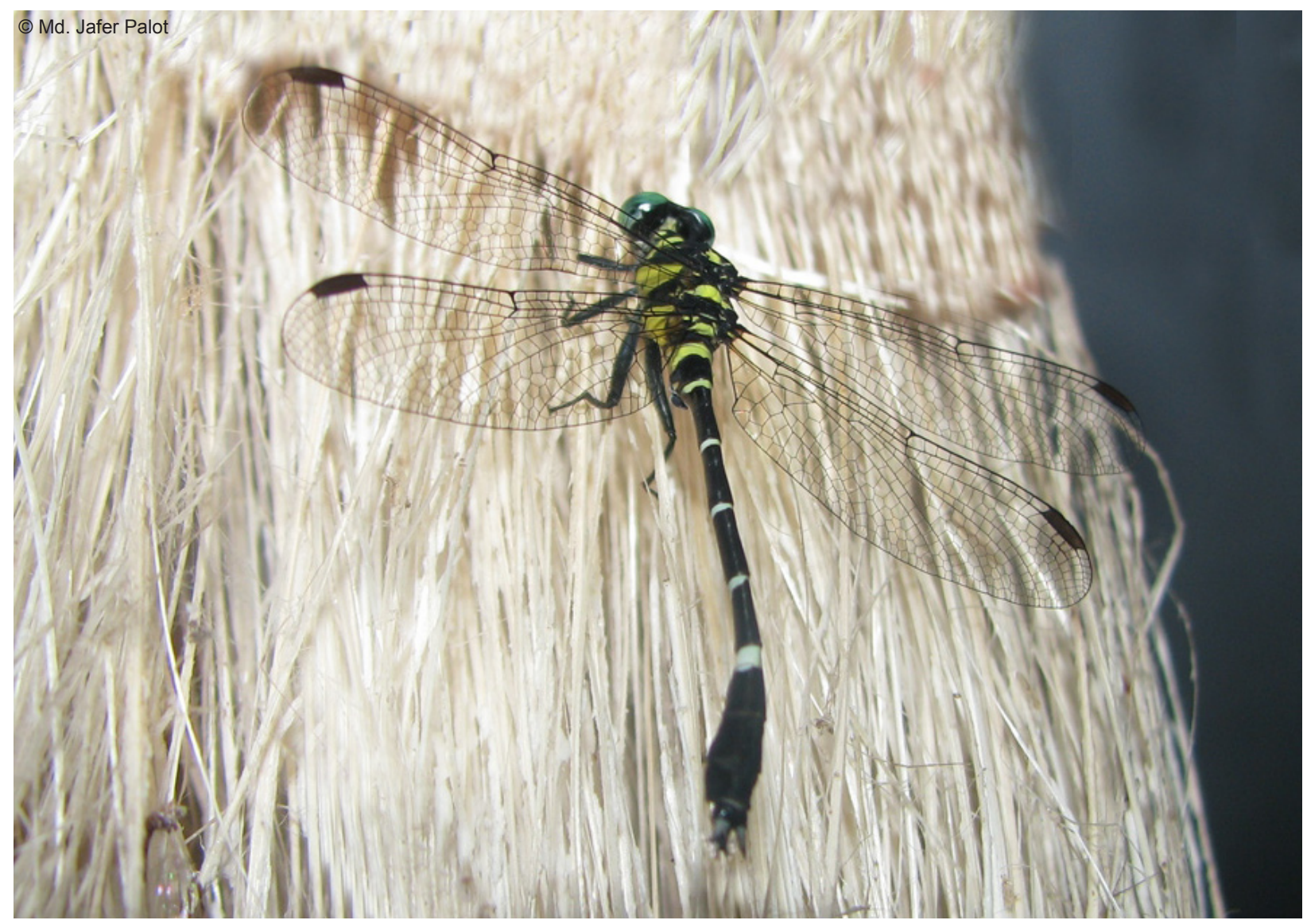

Image 2. Adult male Microgomphus souteri at Aralam Wildlife Sanctuary

souteri Fraser, 1924, M. torquatus (Selys, 1854) and M. verticalis (Selys, 1873) (Subramanian 2009). Of these, only $M$. souteri is endemic to the Western Ghats (Prasad \& Varshney 1995).

The characters of the specimen collected tally (though with some minor variations) with that of $M$. souteri (Fraser 1924). The genus Microgomphus and the species $M$. souteri Fraser is reported here for the first time from Kerala. The morphometric details of the specimen are given below with their diagnostic characters.

\section{Microgomphus souteri Fraser (Image 2)}

Material examined: 06.vi.2010, 1 male, Aralam Wildlife Sanctuary, Kannur District, Kerala, India, coll. Muhamed Jafer Palot, Registration No. ZSI/ WGRC/IR-INV-2240.

Measurements: Total length - 40mm; Abdomen 28mm; Forewing - 25mm; Hindwing - 23mm.

Diagnostic characters: Antehumeral stripes on thorax not confluent with mesothoracic collar; vertex without marking; labrum black, marked with two large triangular greenish spots; abdominal segments 4 and 5 without mid dorsal oval yellow spots; 8 to 10 without yellow markings.

However, we have observed minor variations from the description: anterior collar of prothorax black, two large yellow spots on either side; antehumeral stripe broad, short; mesepimeron and metepimeron yellow, separated by a thin black stripe at the posterolateral suture; undersurface of all coxae and thorax yellowish with white pruinescence; wings with pale yellow at the subcostal and cubital spaces extended up to one cell length; marking on abdominal segments similar, but apicolateral spot absent on segment 2; markings on segment 6 bilobed and on $7^{\text {th }}$ segment not overlapping the transverse suture.

Fraser (1924) described Microgomphus torquatus souteri based on a specimen collected from Coorg, Karnataka. According to Fraser (1934), the species is confined to Coorg and South Kanara and breeds in 
Sampaji and Hallery Rivers and the Kibribetta stream, 609-1067 m, Coorg. The present collection locality of the species from Kerala is however, only about $40-50$ $\mathrm{km}$ south of the type locality of the species. With the present discovery, a total of 139 species of dragonflies and damselflies (Odonata) representing 81 genera are now known to occur in Kerala. The specimen studied is deposited in the faunal depository of the Western Ghat Regional Centre, Zoological Survey of India, Kozhikode, Kerala.

Distribution: India: Kodagu, Dakshina Kannada (Karnataka) and Kannur (Kerala) - present report.

\section{REFERENCES}

Emiliyamma, K.G. \& C. Radhakrishnan (2006). First report of Cyclogomphus heterostylus Selys (Odonata: Insecta) from Kerala, South India. Records of Zoological Survey of India 106(Part-2): 123-124.

Emiliyamma, K.G., C. Radhakrishnan \& M.J. Palot (2007). Odonata (Insecta) of Kerala. Zoological Survey of India, Kolkata, 243pp.

Fraser, F.C. (1924). Microgomphus torquatus souteri Fraser, Records of Indian Museum 26: 427, 474.

Fraser, F.C. (1934). The Fauna of British India Including Ceylon and Burma. Odonata-Vol. 2. Taylor \& Francis Ltd., London, 398pp.

Prasad, M. \& R.K. Varshney (1995). A checklist of the odonata of India including data on larval studies. Oriental Insects 29: 385-428.

Subramanian, K.A. (2009). A Checklist of Odonata (Insecta) of India: 1-36. http://www.zsi.gov.in/checklist/Odonata/ pdf. Downloaded on 20 December 2010. 